\title{
SELECTION OF Metarhizium anisopliae (METSCH.) AND Beauveria bassiana (BALS.) ISOLATES TO CONTROL Alabama argillacea (HUEBNER) CATERPILLARS
}

\author{
Everardo César Filho ${ }^{1,2}$; Edmilson Jacinto Marques ${ }^{1 *}$; Reginaldo Barros ${ }^{1}$ \\ ${ }^{1}$ Depto. de Agronomia - Fitossanidade - UFRPE, R. Dom Manoel de Medeiros s/n Dois irmãos - CEP: 52171-900 - \\ Recife, $P E$. \\ ${ }^{2}$ Pós-Graduado em Fitossanidade - Entomologia - UFRPE. \\ ${ }^{*}$ Corresponding author<emar@ufpe.br>
}

\begin{abstract}
The cotton leafworm, Alabama argillacea (Huebner, 1818) (Lepidoptera: Noctuidae), is considered to be one of the key pests in herbaceous cotton (Gossypium hirsutum L. r. latifolium Hutch) cropping, with constant occurrence in all cotton-growing states of Brazil. In this study Metarhizium anisopliae and Beauveria bassiana isolates were screened and evaluated for pathogenicity against Alabama argillaceae. Initially, a screening of ten isolates of each fungus in a concentracion of $10^{8}$ conidia $\mathrm{mL}^{-1}$, was carried out on $3^{\text {rd }}$ instar larvae of $A$. argillacea. Further studies were conducted to determine the pathogenicity and virulence of six and seven isolates of $M$. anisopliae and $B$. bassiana, respectively, against $3^{\text {rd }}$ instar larvae of $A$. argillacea and using the concentrations of $10^{6}, 10^{7}, 10^{8}$, and $10^{9}$ conidia $\mathrm{mL}^{-1}$. The experiments were carried out in Recife, $\mathrm{PE}$, Brazil, at $27 \pm 2^{\circ} \mathrm{C}, \mathrm{RH} 70 \pm 5 \%$ and a photophase of 12 hours. Mortalities caused by $M$. anisopliae isolate at the different concentrations ranged from 4.5 to $91.2 \%$, the highest mortality percentage being found for the isolate 1189 at $10^{9}$ conidia $\mathrm{mL}^{-1}$. The isolate 645 of $B$. bassiana caused the highest mortality at the highest concentration, followed by isolates 634,604 , and IPA 198. The lowest lethal time for $B$. bassiana and $M$. anisopliae, was achieved by the isolates 483 (4.1 days) and 1189 (2.0 days), respectively. The isolates 1189, 1022 e 866 of $M$. anisopliae and 483, IPA198 and 604 of $B$. bassiana, at $10^{8}$ e $10^{9}$ conidia $\mathrm{mL}^{-1}$ are promissing for use the integrated control of $A$. argillacea larvae, but $M$. anisopliae seems more effective.
\end{abstract}

Key words: entomopathogenic fungus, cotton leafworm, microbial control

\section{SELEÇÃO DE ISOLADOS DE Metarhizium anisopliae (METSCH.) E Beauveria bassiana (BALS.) PARA O CONTROLE DE LAGARTAS DE Alabama argillacea (HUEBNER)}

\begin{abstract}
RESUMO: O curuquerê-do-algodoeiro (Alabama argillacea) é considerado uma das principais pragas do algodoeiro herbáceio no Brasil, com ocorrência comum em vários estágios de crescimento da cultura. Este trabalho avaliou a patogenicidade e selecionou isolados dos fungos entomopatogênicos Metarhizium anisopliae e Beauveria bassiana, para lagartas do curuquerê-do-algodoeiro Alabama argillacea. Os experimentos foram conduzidos a $27 \pm 2^{\circ} \mathrm{C}, 70 \pm 5 \%$ de UR e fotofase de $12 \mathrm{~h}$. Foram utilizados 10 isolados de cada fungo na concentração de $10^{8}$ conídios $\mathrm{mL}^{-1}$ sobre larvas de $A$. argillacea no $3^{\circ}$ instar. Os isolados selecionados (seis de $M$. anisopliae e sete de $B$. bassiana) foram pulverizados com micropulverizador manual (DeVilbiss) nas concentrações de $10^{6}, 10^{7}, 10^{8}$ e $10^{9}$ conídios $\mathrm{mL}^{-1}$, em delineamento inteiramente casualizado. As porcentagens de mortalidade confirmada de lagartas de $A$. argillacea ocasionadas pelos isolados de $M$. anisopliae, variaram de 4,5 a 91,2\%, nas diferentes concentrações, sendo que o isolado 1189 de $M$. anisopliae, na concentração $10^{9}$ conídios $\mathrm{mL}^{-1}$, proporcionou a maior mortalidade. O isolado 645 de $B$. bassiana, também proporcionou a mais elevada mortalidade na concentração $10^{9}$ conídios $\mathrm{mL}^{-1}$, seguido dos isolados 634 , IPA 198 e 604 . O isolado 1189 de $M$. anisopliae apresentou o tempo letal $\left(\mathrm{TL}_{50}\right)$ igual a 2,0 dias, sendo portanto menor que os demais isolados, na concentração de $10^{9}$ conídios $\mathrm{mL}^{-1}$. Para B. bassiana, o menor $\mathrm{TL}_{50}$ foi do isolado 483 (4,1 dias). Os isolados 1189, 1022 e 866 de M. anisopliae e 483, IPA198 e 604 de B. bassiana nas concentrações $10^{8}$ e $10^{9}$ conídios $\mathrm{mL}^{-1}$, mostraram-se promissores para incorporação no manejo integrado de $A$. argillacea, destacando-se aqueles de $M$. anisopliae.

Palavras-chave: fungo entomopatogênico, curuquerê-do-algodoeiro, controle microbiano
\end{abstract}

\section{INTRODUCTION}

The cotton leafworm, is considered to be one of the key pests in herbaceous cotton crops, with constant occurrence in all cotton-growing states of Brazil. In the Brazilian Northeast, infestation normally occurs beginning in March, when plant emergence takes place (Bleicher et al., 1990). In other regions, this pest can occur in different seasons, depending on the environmental conditions, especially rainfall and relative humidity (Domiciano \& Santos, 1994; Ramalho, 1994). When the attack of cotton leafworms occurs in the first 45 days of crop development, it can cause significant loss of foliage in the main stem, resulting in irreversible damage to the 
succeeding phenological stages of the plant (Bleicher et al., 1983).

Leafworm control must start in fields with less than 110 days after germination when 10 medium-sized (larger than $15 \mathrm{~mm}$ ) caterpillars are found in 10 examined plants, or, in fields with more than 110 days after germination, when 20 medium-sized caterpillars are found in 10 examined plants (Cruz, 1989). Control is done with the use of chemicals (Jesus et al., 1984) and through biological control (Bleicher \& Parra, 1990; Almeida, 1996). In spite of the importance of natural biological control for this pest, not many reports can be found on the use of biological control agents to suppress $A$. argillacea caterpillars, either with predators, parasitoids or entomopathogens (Allen, 1977; Bleicher \& Parra, 1990; Chocorosqui \& Pasini, 2000).

Entomopathogenic fungi, such as Beauveria bassiana (Bals.) Vuill. and Metarhizium anisopliae (Metsch.) Sorok., are produced and formulated in several regions in Brazil, in order to control pests belonging to many orders, including Lepidoptera (Ferron, 1978; Marques et al., 1981; Alves, 1998). The vast genetic variability found in these entomopathogens endorse them as important insect microbial control agents. These fungi are completely compatible with the purposes established for the integrated pest management, since isolates obtained from one insect species can be pathogenic to other species that are distant from a taxonomic standpoint and not only to closely-related species (Alves et al., 1984; Alves, 1998).

$B$. bassiana isolates have proven to be pathogenic to fall armyworm, Spodoptera frugiperda (J. E. Smith) (Rodrigues \& Pratissoli, 1989; França et al., 1989; Faria et al., 1992). At a concentration of $1.64 \times 10^{9}$ conidia $\mathrm{mL}^{-1}$, the fungus $B$. bassiana gave $60 \%$ mortality against Castnia licus (Drury) larvae (Vilas Boas et al., 1983). High mortality levels of $C$. licus larvae caused by the fungi $B$. bassiana and Beauveria brongniartii (Sacc.) Petch, were also observed by Vilas Boas \& Alves (1988). The fungi $M$. anisopliae and $B$. bassiana, at a concentration of $10^{8}$ conidia $\mathrm{mL}^{-1}$, caused mortality of Castnia icarus (Cramer) larvae on the order of 68.8 and $54.0 \%$, respectively (Silva \& Veiga, 1998). The species Cydia pomonella (Linnaeus); Ostrinia nubilalis (Huebner); Diatraea saccharalis (Fabricius); and, Plutella xylostella (Linnaeus), are also susceptible to the fungi $M$. anisopliae and B. bassiana (Alves, 1998).

Given the importance represented by cotton leafworms to cotton cropping in Brazil and the lack of research on the use of entomopathogens for their control, this project aimed to evaluate their pathogenicity and select isolates of $M$. anisopliae and $B$. bassiana for the control of $A$. argillacea in the laboratory.

\section{MATERIAL AND METHODS}

Experiments were performed at the Insect Pathology Laboratory of Universidade Federal Rural de
Pernambuco (UFRPE), at a temperature of $27 \pm 2^{\circ} \mathrm{C}, 70 \pm 5$ $\% \mathrm{RH}$ and $12 \mathrm{~h}$ photophase.

Insect rearing and maintenance: Initially, $A$. argillacea pupae were obtained from CNPA-EMBRAPA, Campina Grande - PB. After emergence, the adults were transferred into PVC tube cages, measuring $20 \mathrm{~cm}$ in height and $19.5 \mathrm{~cm}$ in diameter, placed over a paper towel and covered with organza fabric. The internal wall of the cage was lined with a sheet of white paper to allow removal of egg masses. Five couples were maintained per cage. The adults were fed a $30 \%$ honey solution, offered on pieces of plastic foam $1.0 \mathrm{~cm}$ thick and 3.0 $\mathrm{cm}$ in diameter, enclosed in plastic lids. Water was provided by means of a cotton wad inserted into small glass vials $(20 \mathrm{~mL})$. Every other day the eggs were collected and transferred to cages identical to those used for the adults. Leaves from the upper part of cotton plants, cultivar CNPA Precoce 1, with their petioles immersed into small glass containers filled with water, were provided daily as food for the caterpillars. Removal of faecal material was also performed daily. This colony was maintained for several generations until the conclusion of the experiments.

Acquisition of fungi isolates: The $B$. bassiana and $M$. anisopliae fungi isolates used in the experiments can be found in the collection of the Insect Pathology Laboratory, in the Plant Protection Area - UFRPE (Table 1), where they are stored at temperature $7^{\circ} \mathrm{C}$, in glass tubes containing Potato - Dextrose - Agar culture medium plus antibiotic (chloramphenicol) (BDA + A) and Nujol oil. When tests were performed the isolates were subcultured and multiplied on BDA + A or on Complete Medium (CM), the latter containing minerals, glucose, yeast extract and agar, and then placed in a B.O.D. incubator at $26 \pm 1^{\circ} \mathrm{C}$ and $12 \mathrm{~h}$ photophase.

Selection of the most pathogenic isolates: During this step, $10 \mathrm{M}$. anisopliae and $10 \mathrm{~B}$. bassiana isolates were obtained from $\mathrm{CM}$ dishes ten days after plating. Then, $203^{\text {rd }}$-instar $A$. argillacea caterpillars were sprayed with $2 \mathrm{~mL}$ of suspension for each isolate with a manual microsprayer (DeVilbiss), at the concentration of $10^{8}$ conidia $\mathrm{mL}^{-1}$. Suspensions were prepared with sterile water containing $0.1 \%$ Tween $80^{R}$. After that, caterpillars were transferred to PVC cages, fed with cotton leaves and observed daily until ten days after inoculation. Concurrently, isolate viability was verified by plating on $\mathrm{BDA}+\mathrm{A}$, and making an observation 24h later under the optical microscope, with three counts (replicates) of 100 conidia each.

Dead caterpillars were transferred to Petri dishes lined with slightly moistened filter paper and placed in a B.O.D. incubator at $26 \pm 1^{\circ} \mathrm{C}$ and $12 \mathrm{~h}$ photophase, in order to confirm the causal agent and to verify conidiogenesis. Only isolates that provided confirmed mortality were selected, i.e., only those $A$. argillacea caterpillars that showed fungal development higher than $50 \%$. 
Table 1 - Metarhizium anisopliae and Beauveria bassiana isolates, origins and hosts.

\begin{tabular}{|c|c|c|}
\hline Isolate & Origin & Host \\
\hline \multicolumn{3}{|c|}{ M. anisopliae } \\
\hline PL 47 & Lab. of Insect Pathology (USP/ESALQ) & Mahanarva posticata \\
\hline 1022 & $"$ & Phyllophaga sp. \\
\hline 1172 & " & Soil sample \\
\hline PL 43 & $"$ & Mahanarva posticata \\
\hline 866 & $"$ & Atta sp. \\
\hline UOD & Lab. of Insect Pathology (UFRPE) & Castnia licus \\
\hline E 9 & Lab. of Insect Pathology (USP/ESALQ) & Deois flavopicta \\
\hline IPA 207 & IPA (PE) Enterprise & Mahanarva posticata \\
\hline IPA 204 & IPA (PE) Enterprise & Mahanarva posticata \\
\hline 1189 & Lab. of Insect Pathology (USP/ESALQ) & Soil sample \\
\hline \multicolumn{3}{|c|}{ B. bassiana } \\
\hline 483 & Lab. of Insect Pathology (USP/ESALQ) & Solenop sis invicta \\
\hline 512 & " & Solenop sis invicta \\
\hline 561 & $"$ & Solenopsis sp. \\
\hline 447 & $"$ & Solenopsis invicta \\
\hline 645 & $"$ & Soil sample \\
\hline 604 & $"$ & Soil sample \\
\hline 634 & $"$ & Solenopsis invicta \\
\hline 635 & $"$ & Solenop sis invicta \\
\hline 610 & $"$ & Amostra de Solo \\
\hline IPA 198 & IPA (PE) Enterprise & Cosmopolites sordidus \\
\hline
\end{tabular}

Production of select $M$. anisopliae and $B$. bassiana isolates: Isolate production was started based on cultures obtained from re-isolation of $A$. argillacea. Later, conidia were multiplied in bottles $(500 \mathrm{~mL})$ containing rice as culture medium. Bottles were prepared with 140 grams of parboiled rice and $90 \mathrm{~mL}$ distilled water, sealed with aluminum foil and a piece of string, and autoclaved at $120^{\circ} \mathrm{C}$ for 20 minutes, according to an adaptation from the methodology of Marques et al. (1981). After cooling off, the rice was inoculated with $15 \mathrm{~mL}$ of a conidia suspension of each isolate, at the concentration of $10^{7}$ conidia $\mathrm{mL}^{-1}$. Bottles were maintained for 10 days in a B.O.D. incubator, at $26 \pm 1^{\circ} \mathrm{C}$ and $12 \mathrm{~h}$ photophase.

Select isolate virulence evaluation: Two experiments with a completely randomized factorial design were carried out for the isolate virulence tests; the first experiment consisted of $6 \mathrm{M}$. anisopliae isolates in 4 concentrations; the second was performed 15 days later, with $7 \mathrm{~B}$. bassiana isolates in 4 concentrations. Three replicates consisting of $103^{\text {rd }}$ instar $A$. argillacea caterpillars were utilized for each treatment, totaling 30 caterpillars per treatment. The caterpillars were placed on Petri dishes and sprayed with $2 \mathrm{~mL}$ of the $M$. anisopliae isolate suspensions in the first experiment, and the $B$. bassiana in the second, at concentrations of $10^{6} ; 10^{7} ; 10^{8}$; and, $10^{9}$ conidia $\mathrm{mL}^{-1}$, by using a manual microsprayer (DeVilbiss), akin to the initial step. Controls were sprayed with distilled water plus Tween $80^{R}$ at $0.1 \%$. Then, caterpillars were transferred to the PVC cages, as previously described, and maintained according to the rearing procedures adopted for them. The numbers of dead caterpillars were recorded daily for 10 days, and the larvae were transferred to humid chambers for confirmation of mortality by the pathogens. Isolate efficiency was evaluated by means of the confirmed mortality percentage, caterpillars that showed fungus development, and corrected in relation to the control by Abbott's (1925) formula. Lethal time $\left(\mathrm{LT}_{50}\right)$ determination was performed through Probit analysis, by using the software MOBAE (Haddad et al., 1995). Caterpillar mortality percentages were submitted to analysis of variance and the means compared by the Tukey test $(P \leq 0,05)$.

\section{RESULTS AND DISCUSSION}

Selection of the most pathogenic isolates: Conidia viability for the $M$. anisopliae and $B$. bassiana isolates was higher than $95 \%$ in all experiments. The confirmed mortality of $A$. argillacea caterpillars, 10 days after inoculation, ranged from 10 to $70 \%$ and from 25 to $70 \%$, for $M$. anisopliae and B. bassiana, respectively (Table 2). Differences in mortality for caterpillars treated with different isolates demonstrated the importance of the selection. Isolates 1189; 1022; PL 47; IPA 204; 1172; and 866 of $M$. anisopliae and 610 ; $561 ; 634 ; 604$; IPA 198; 483; and 645 of $B$. bassiana were selected after the first bioassay, since they caused confirmed caterpillar mortalities above $50 \%$. This selection criterion was the chosen option, due to the likelihood of obtaining isolates with a higher potential for a possible utilization in the management of the pest. 
Isolate virulence evaluation: At the concentration $10^{9}$ conidia $\mathrm{mL}^{-1}$, a variation occurred ranging from 56.7 to $91.2 \%$ as confirmed mortality (Table 3 ). All selected $M$. anisopliae isolates caused mortality of $A$. argillacea above $50 \%$, indicating that isolate 1189 caused the highest mortality, at both concentrations of $10^{9}$ and $10^{8}$ conidia $\mathrm{mL}^{-1}$ (Table 3). At a concentration of $10^{8}$ conidia $\mathrm{mL}^{-1}$, isolates 1189 and 1022 caused mortality of $A$. argillacea

Table 2 - Confirmed mortality of Alabama argillacea caterpillars, by Metarhizium anisopliae and Beauveria bassiana isolates at a concentration of $10^{8}$ conidia $\mathrm{mL}^{-1}$, ten days after inoculation. Temperature: $27 \pm 2{ }^{\circ} \mathrm{C}, \mathrm{RH}: 70 \pm 5 \%$ and photophase: $12 \mathrm{~h}$.

\begin{tabular}{lccc}
\hline M. anisopliae & Mortality $^{1}$ & B. bassiana & Mortality $^{1}$ \\
\hline & $----\%$--- & & $---\%_{---}$ \\
\hline 1189 & 70 & 604 & 70 \\
1022 & 65 & 561 & 60 \\
866 & 65 & PPA 198 & 60 \\
PL 47 & 60 & 634 & 60 \\
\hline PA 204 & 60 & 610 & 55 \\
1172 & 55 & 645 & 55 \\
E9 & 30 & 483 & 55 \\
PL 43 & 30 & 635 & 40 \\
IPA 207 & 25 & 512 & 30 \\
UOD & 10 & 447 & 25 \\
\hline
\end{tabular}

${ }^{1}$ Confirmed mortality: insects with conidiogenesis. caterpillars above $70 \%$, which are values comparable to those observed by Silva \& Veiga (1998) when they used this fungus against $C$. icarus larvae. On the other hand, at a concentration of $10^{7}$ conidia $\mathrm{mL}^{-1}$, only isolates 1189 and 866 caused mortalities higher than $50 \%$, with isolate 1189 killing $60.1 \%$ of the caterpillars. Using a similar concentration, Rodrigues \& Pratissoli (1989) verified that $M$. anisopliae was not pathogenic to $S$. frugiperda caterpillars. At the concentration of $10^{6}$ conidia $\mathrm{mL}^{-1}$, all $M$. anisopliae isolates caused mortalities below $25 \%$.

For $B$. bassiana, at the concentration of $10^{9}$ conidia $\mathrm{mL}^{-1}$, mortalities obtained with all isolates were higher than $60 \%$; however, the isolates did not differ statistically from each other, and the highest mortality of $A$. argillacea caterpillars was observed with isolate $645(80.7 \%)$ (Table $3)$. These results are similar to those obtained by França et al. (1989) and Faria et al. (1992), when they worked with other $B$. bassiana isolates and verified high mortalities of $S$. frugiperda caterpillars. At a concentration of $10^{8}$ conidia $\mathrm{mL}^{-1}$, according to what was verified during the initial selection phase, isolates caused mortalities over $50 \%$, with isolate 604 being prominent, since it was not different at concentrations of $10^{9}$ and $10^{8}$ conidia $\mathrm{mL}^{-1}$. At concentrations of $10^{7}$ and $10^{6}$ conidia $\mathrm{mL}^{-1}$, B. bassiana isolates caused caterpillar mortalities below 40.0 and $25.0 \%$, respectively, which are levels similar to those recorded by Rodrigues \& Pratissoli (1989) when they applied $B$. bassiana at the concentration of $10^{7}$ conidia $\mathrm{mL}^{-1}$ against $S$. frugiperda caterpillars, observing mortality levels of $40.0 \%$.

Table 3 - Confirmed mortality (\%) of Alabama argillacea caterpillars, by Metarhizium anisopliae and Beauveria bassiana isolates and conidia concentrations. Temperature: $27 \pm 2{ }^{\circ} \mathrm{C}, \mathrm{RH}: 70 \pm 5 \%$, photophase: $12 \mathrm{~h}$.

\begin{tabular}{|c|c|c|c|c|}
\hline \multirow[t]{2}{*}{ Treatment isolate } & \multicolumn{4}{|c|}{ Mortality ${ }^{1}$} \\
\hline & $10^{9}$ conidia $\mathrm{mL}^{-1}$ & $10^{8}$ conidia $\mathrm{mL}^{-1}$ & $10^{7}$ conidia $\mathrm{mL}^{-1}$ & $10^{6}$ conidia $\mathrm{mL}^{-1}$ \\
\hline & \multicolumn{4}{|c|}{ Metarhizium anisopliae } \\
\hline 1189 & $91.2 \pm 1.53 \mathrm{Aa}$ & $71.6 \pm 2.00 \mathrm{ABa}$ & $60.1 \pm 1.00 \mathrm{Ba}$ & $16.3 \pm 0.58 \mathrm{Ca}$ \\
\hline 1022 & $73.5 \pm 0.58 \mathrm{Aab}$ & $70.8 \pm 1.73 \mathrm{ABa}$ & $36.6 \pm 0.58 \mathrm{Bab}$ & $4.5 \pm 0.58 \mathrm{Ca}$ \\
\hline 866 & $73.5 \pm 0.58 \mathrm{Aab}$ & $66.7 \pm 0.58 \mathrm{Aa}$ & $53.3 \pm 2.08 \mathrm{Aab}$ & $6.7 \pm 1.00 \mathrm{Ba}$ \\
\hline PL 47 & $71.6 \pm 2.00 \mathrm{Aab}$ & $53.3 \pm 0.58 \mathrm{Aa}$ & $35.1 \pm 2.08 \mathrm{ABab}$ & $11.6 \pm 1.53 \mathrm{Ba}$ \\
\hline IPA 204 & $64.0 \pm 2.08 \mathrm{Aab}$ & $63.4 \pm 0.58 \mathrm{Aa}$ & $19.3 \pm 1.00 \mathrm{Bb}$ & $15.7 \pm 1.15 \mathrm{Ba}$ \\
\hline \multirow[t]{2}{*}{1172} & $56.7 \pm 0.58 \mathrm{Ab}$ & $50.1 \pm 1.73 \mathrm{ABa}$ & $20.0 \pm 0.00 \mathrm{ABb}$ & $22.1 \pm 1.53 \mathrm{Ba}$ \\
\hline & \multicolumn{4}{|c|}{ Beauveria bassiana } \\
\hline 645 & $80.7 \pm 1.00 \mathrm{Aa}$ & $50.0 \pm 0.00 \mathrm{ABa}$ & $18.3 \pm 1.73 \mathrm{BCa}$ & $4.5 \pm 0.58 \mathrm{Ca}$ \\
\hline 634 & $77.8 \pm 1.53 \mathrm{Aa}$ & $60.6 \pm 2.00 \mathrm{ABa}$ & $39.8 \pm 1.00 \mathrm{BCa}$ & $19.3 \pm 1.00 \mathrm{Ca}$ \\
\hline IPA 198 & $76.2 \pm 2.89 \mathrm{Aa}$ & $67.2 \pm 1.53 \mathrm{Aa}$ & $29.7 \pm 1.00 \mathrm{Ba}$ & $23.8 \pm 0.58 \mathrm{Ba}$ \\
\hline 604 & $73.8 \pm 1.15 \mathrm{Aa}$ & $73.5 \pm 0.58 \mathrm{Aa}$ & $32.9 \pm 1.15 \mathrm{Ba}$ & $1.1 \pm 0.58 \mathrm{Ca}$ \\
\hline 610 & $65.1 \pm 3.06 \mathrm{Aa}$ & $53.3 \pm 1.15 \mathrm{ABa}$ & $26.5 \pm 0.58 \mathrm{BCa}$ & $4.5 \pm 0.58 \mathrm{Ca}$ \\
\hline 483 & $63.4 \pm 0.58 \mathrm{Aa}$ & $54.0 \pm 2.31 \mathrm{Aa}$ & $6.7 \pm 1.00 \mathrm{Ba}$ & $4.5 \pm 0.58 \mathrm{Ba}$ \\
\hline 561 & $60.0 \pm 1.73 \mathrm{Aa}$ & $60.1 \pm 1.00 \mathrm{Aa}$ & $32.8 \pm 1.53 \mathrm{ABa}$ & $6.7 \pm 1.00 \mathrm{Ba}$ \\
\hline
\end{tabular}

${ }^{1}$ Means ( \pm DP) followed by the same upper case letter, in the row, and lower case letter, in the column, are not different by Tukey test at $5 \%$.

${ }^{1}$ Transformation as arcsine of square root of $\mathrm{x} / 100$.

CV $=23.20 \%$ (M. anisopliae) - CV $=26.02 \%$ (B. bassiana) 
A positive relationship was recorded between mortality percentages and concentrations among the $M$. anisopliae and $B$. bassiana isolates, just as expected. Concurrently, with the increase in conidia concentration, a reduction in $\mathrm{LT}_{50}$ was observed. Isolate 1189 from $M$. anisopliae, at the concentrations $10^{8}$ and $10^{9}$ conidia $\mathrm{mL}^{-1}$, presented the shortest lethal time (Table 4). These low values are probably associated to the presence of enzymes that aid in the process of penetration of the fungi (St. Leger et al. 1988), as well as toxins such as the destruxins, which cause variability among isolates, endowing this isolate with higher virulence against $A$. argillacea caterpillars. For $B$. bassiana at a concentration of $10^{9}$ conidia $\mathrm{mL}^{-1}$, variation in $\mathrm{LT}_{50}$ ranged from 4.1 to 6.4 days. Isolate 483 presented the shortest $\mathrm{LT}_{50}$ for this rate, whereas at a concentration of $10^{8}$ conidia $\mathrm{mL}^{-1}$, the isolates showing the shortest $\mathrm{LT}_{50}$ were 634 and 604, with an $\mathrm{LT}_{50}$ of 5.7 days (Table 5 ). Isolates of the fungi $M$. anisopliae and $B$. bassiana at concentrations of $10^{8}$ and $10^{9}$ conidia $\mathrm{mL}^{-1}$ utilized in this research demonstrated to be promising for incorporation to an integrated management scheme against $A$. argillacea.

Table 4 - Lethal time $\left(\mathrm{LT}_{50}\right)$ for Metarhizium anisopliae isolates against Alabama argillacea caterpillars. Temperature: 27 $\pm 2^{\circ} \mathrm{C}, \mathrm{RH}: 70 \pm 5 \%$ and photophase: $12 \mathrm{~h}$.

\begin{tabular}{|c|c|c|c|c|}
\hline Isolate & Conidia concentration $\mathrm{mL}^{-1}$ & $\mathrm{LT}_{50}$ and $\mathrm{IC}^{*}$ (Day) & Equation & $x^{2}$ \\
\hline \multirow[t]{3}{*}{1189} & $10^{9}$ & $2.0(1.9-2.2)$ & $Y=4.02+3.22 \log x$ & $0.02^{*}$ \\
\hline & $10^{8}$ & $3.6(2.9-4.4)$ & $Y=2.57+4.38 \log x$ & $1.09^{*}$ \\
\hline & $10^{7}$ & $4,9(4.0-6.2)$ & $Y=2.97+2.91 \log x$ & $1.41^{*}$ \\
\hline \multirow[t]{2}{*}{1022} & $10^{9}$ & $4.3(3.7-5.1)$ & $Y=3.41+2.49 \log x$ & $0.70^{*}$ \\
\hline & $10^{8}$ & $6.9(5.9-7.9)$ & $Y=0.23+5.70 \log x$ & $3.12^{*}$ \\
\hline \multirow[t]{2}{*}{ PL 47} & $10^{9}$ & $6.6(5.8-7.4)$ & $Y=0.39+5.65 \log x$ & $4.13^{*}$ \\
\hline & $10^{8}$ & $7.7(6.8-8.7)$ & $Y=2.35+3.00 \log x$ & $1.55^{*}$ \\
\hline \multirow[t]{2}{*}{ IPA 204} & $10^{9}$ & $6.3(5.6-7.1)$ & $Y=2.45+3.18 \log x$ & $0.68^{*}$ \\
\hline & $10^{8}$ & $6.6(5.7-7.6)$ & $Y=2.91+2.55 \log x$ & $1.38^{*}$ \\
\hline \multirow[t]{2}{*}{1172} & $10^{9}$ & $7.6(6.4-8.9)$ & $Y=0.15+5.52 \log x$ & $5.71^{*}$ \\
\hline & $10^{8}$ & $8.5(7.4-9.7)$ & $Y=2.22+2.99 \log x$ & $0.81^{*}$ \\
\hline \multirow[t]{3}{*}{866} & $10^{9}$ & $4.8(4.6-5.1)$ & $Y=0.56+6.47 \log x$ & $0.17^{*}$ \\
\hline & $10^{8}$ & $5.8(5.1-6.6)$ & $Y=1.30+4.85 \log x$ & $2.59^{*}$ \\
\hline & $10^{7}$ & $7.3(6.3-8.5)$ & $Y=1.58+3.95 \log x$ & $0.92^{*}$ \\
\hline
\end{tabular}

${ }^{*}$ Confidence interval (Significance at the $5 \%$ ).

Mortality did not reach $50 \%$ for all isolates at a concentration of $10^{6}$ conidia $\mathrm{mL}^{-1}$, and for isolates 1022; PL 47; IPA 204; and 1172 at a concentration of $10^{7}$ conidia $\mathrm{mL}^{-1}$.

Table 5 - Lethal time $\left(\mathrm{LT}_{50}\right)$ for Beauveria bassiana isolates over Alabama argillacea caterpillars. Temperature: $27 \pm 2^{\circ} \mathrm{C}$, $\mathrm{RH}: 70 \pm 5 \%$ and photophase: $12 \mathrm{~h}$.

\begin{tabular}{|c|c|c|c|c|}
\hline Isolate & Conidia concentration $\mathrm{mL}^{-1}$ & $\mathrm{LT}_{50}$ and $\mathrm{IC}^{*}$ (Day) & Equation & $x^{2}$ \\
\hline \multirow[t]{2}{*}{610} & $10^{9}$ & $6.4(5.9-7.1)$ & $Y=0.78+5.21 \log x$ & $1.76^{*}$ \\
\hline & $10^{8}$ & $6.8(6.3-7.4)$ & $Y=-1.02+7.21 \log x$ & $0.01^{*}$ \\
\hline \multirow[t]{2}{*}{561} & $10^{9}$ & $5.3(4.6-6.1)$ & $Y=2.83+3.00 \log x$ & $0.87^{*}$ \\
\hline & $10^{8}$ & $6.5(5.9-7.2)$ & $Y=1.39+4.44 \log x$ & $1.34^{*}$ \\
\hline \multirow[t]{2}{*}{634} & $10^{9}$ & $5.3(4.8-5.8)$ & $Y=-0.05+6.97 \log x$ & $0.60^{*}$ \\
\hline & $10^{8}$ & $5.8(4.7-7.0)$ & $Y=2.06+3.87 \log x$ & $0.77^{*}$ \\
\hline \multirow[t]{2}{*}{604} & $10^{9}$ & $4.5(4.0-5.2)$ & $Y=0.96+6.13 \log x$ & $0.92^{*}$ \\
\hline & $10^{8}$ & $5.7(5.0-6.6)$ & $Y=-2.16+9.44 \log x$ & $2.01^{*}$ \\
\hline \multirow[t]{2}{*}{ IPA 198} & $10^{9}$ & $4.4(3.6-5.2)$ & $Y=2.75+3.52 \log x$ & $1.89^{*}$ \\
\hline & $10^{8}$ & $5.9(5.3-6.6)$ & $Y=1.67+4.32 \log x$ & $2.16^{*}$ \\
\hline \multirow[t]{2}{*}{645} & $10^{9}$ & $4.9(4.4-5.5)$ & $Y=1.93+4.42 \log x$ & $1.91^{*}$ \\
\hline & $10^{8}$ & $7.9(7.2-8.8)$ & $Y=-0.82+6.46 \log x$ & $0.67^{*}$ \\
\hline \multirow[t]{2}{*}{483} & $10^{9}$ & $4.1(3.5-4.9)$ & $Y=2.61+3.89 \log x$ & $0.03^{*}$ \\
\hline & $10^{8}$ & $6.9(6.1-7.8)$ & $Y=2.78+2.65 \log x$ & $0.74^{*}$ \\
\hline
\end{tabular}

${ }^{*}$ Confidence interval (Significance at the $5 \%$ ).

Mortality did not reach $50 \%$ for all isolates at concentrations of $10^{7}$ and $10^{6}$ conidia $\mathrm{mL}^{-1}$ 


\section{ACKNOWLEDGEMENTS}

To CNPq, for granting a Master's degree scholarship to the first author; to Prof. Jorge Braz Torres and Prof. Irene Maria Ramos Marques, for the suggestions and collaboration.

\section{REFERENCES}

ABBOTT, W. S. A method of computing the effectiveness of na insecticide. Journal of Economic Entomology, v.18, p.265-267, 1925.

ALLEN, R.T. Calosoma alternans granulatum Perty: a predador of cotton leaf worms in Bolivia (Coleoptera: Carabidae: Carabine). The Bulletin of Coleoptera, v.31, p.73-76, 1977.

ALMEIDA, R.P. de. Biotecnologia de produção massal de Trichogramma spp. através de hospedeiro alternativo Sitotroga cerealella. Campina Grande: EMBRAPA, CNPA, 1996. 36p. (Circular Técnica, 19).

ALVES, S.B. Fungos entomopatogênicos. In: ALVES, S.B. (Ed.) Controle microbiano de insetos. Piracicaba: FEALQ, 1998. p.289-381.

ALVES, S.B.; RISCO, S.H.; SILVEIRA NETO, S.; MACHADO NETO, R. Pathogenicity of nine isolates of Metarhizium anisopliae to Diatraea saccharalis. Zeitschrift fur Angewandte Entomology, v.97, p.403-406, 1984.

BLEICHER, R.; MELO, A.B.P. de; JESUS, F.M.M. de; FERRAZ, C.T Distribuição vertical de lagartas de Alabama argillacea (HUEBNER, 1818) Lepidoptera: Noctuidae em plantas de algodoeiro. Anais da Sociedade Entomológica do Brasil, v.12, p.117-121, 1983.

BLEICHER, E.; PARRA, J.R.P. Espécie de Trichogramma parasitóides de Alabama argillacea: II. Tabela de vida de fertilidade e parasitismo de três populações. Pesquisa Agropecuária Brasileira, v.25, p.207-214, 1990.

BLEICHER, E.; JESUS, F.M.M. de; DE SOUZA, S.L. Uso de inseticidas seletivos no controle do curuquerê-do-algodoeiro. Pesquisa Agropecuária Brasileira, v.25, p.277-288, 1990.

CHOCOROSQUI, V.R.; PASINI, A. Predação de pupas de Alabama argillacea (HUEBNER, 1818) (Lepidoptera: Noctuidae) por larvas e adultos de Calosoma granulatum Perty (Coleoptera: Carabidae) em laboratório. Anais da Sociedade Entomológica do Brasil, v.29, p.65-70, 2000.

CRUZ, V.R. da. Instruções para o manejo integrado das pragas do algodão, incluindo o bicudo. Campinas: CATI, 1989. 46p. (Instrução Prática, 244).

DOMICIANO, N.L.; SANTOS, W.J. Momento adequado para aplicação de inseticidas no controle do curuquerê-do-algodoeiro. Pesquisa Agropecuária Brasileira, v.29, p.7-11, 1994.
FARIA, L.L.F. de; OLIVEIRA, J.V.; BARROS, R. Patogenicidade do fungo Beauveria bassiana (Bals.) Vuill., em lagartas de Spodoptera frugiperda (J. E. Smith, 1797) (Lepidoptera: Noctuidae) sob condições de laboratório. Caderno Ômega, v.4, p.207-217, 1992.

FERRON, P. Biological control of insect pests by entomogenous fungi. Annual Review of Entomology, v.23, p.409-442, 1978.

FRANÇA, M.M.; TIGANO, M.S.; CARVALHO, R.S. Suscetibilidade de Spodoptera frugiperda aos fungos entomopatogênicos Beauveria bassiana e Nomuraea rileyi. In: CONGRESSO BRASILEIRO DE ENTOMOLOGIA, 12., Belo Horizonte, 1989. Resumos. Belo Horizonte: SEB, 1989. p.254.

HADDAD, M.L.; MORAES, R.C.B.; PARRA, J.R.P. MOBAE, Modelos bioestatísticos aplicados à entomologia. Piracicaba: ESALQ/USP, 1995. $44 \mathrm{p}$.

JESUS, F.M. de; BLEICHER, E.; CRISÓSTOMO, J.R.; LIMA, E.F. Manejo integrado das pragas do algodoeiro no Brasil, situação e perspectivas. Campina Grande: EMBRAPA, CNPA, 1984. 21p.

MARQUES, E.J.; VILAS BOAS, A.M.; PEREIRA, C.E.F. Orientações técnicas para produção do fungo entomógeno Metarhizium anisopliae (Metsch) em laboratórios setoriais. Piracicaba: PLANALSUCAR, 1981. 23p. (Boletim Técnico, 3)

RAMALHO, F.S. Cotton pest management. Part 4. A Brazilian perspective. Annual Review of Entomology, v.39, p.563-578, 1994.

RODRIGUES, C.; PRATISSOLI, D. Avaliação de patogenicidade dos fungos entomógenos Beauveria bassiana e Metarhizium anisopliae sobre Spodoptera frugiperda (lagarta do cartucho). In: CONGRESSO BRASILEIRO DE ENTOMOLOGIA, 12., Belo Horizonte, 1989. Resumos. Belo Horizonte: SEB, 1989. p.223.

SILVA, R.B.Q. da; VEIGA, A.F. de S.L. Patogenicidade de Beauveria bassiana (Bals.) e Metarhizium anisopliae (Metsch.) Sorok. sobre Castnia icarus (Cramer, 1775). Revista de Agricultura, v.73, p.119-127, 1998.

ST. LEGER, R.J. ; DURRANDS, P.K : CHARNLEY, A.K : COOPER, R.M. Role of extracellular chymoelastase in the virulence of Metarhizium anisopliae for Manduca sexta. Journal of Invertebrate Pathology, v.52, p.285-293, 1988.

VILAS BOAS, A.M.; ALVES, S.B. Patogenicidade de Beauveria spp. e seu efeito associado ao inseticida monocrotofós sobre Castnia licus (Drury, 1770) (Lepidoptera: Castniidae). Anais da Sociedade Entomológica do Brasil, v.17, p.305-332, 1988.

VILAS BOAS, A.M.; MARQUES, E.J.; RIBEIRO, S.M.A. Patogenicidade do fungo Beauveria bassiana (Bals.) Vuill., sobre larvas de Castnia licus (Drury) (Lepidoptera: Castniidae), broca gigante da cana-de-açúcar. Anais da Sociedade Entomológica do Brasil, v.12, p.295-298, 1983.

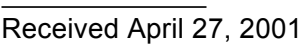

